\title{
Research on Development Countermeasures of Prefabricated Buildings in New Rural Construction -- A Case Study of Longfeng Village, Hunan Province
}

\author{
Ying Zhang ${ }^{1}$, Zuzhan Chen ${ }^{1 *}$, Hongkai Sun ${ }^{1}$, Shili Zhang ${ }^{1}$, Kai Feng ${ }^{1}$, Haoqian Liu ${ }^{1}$ \\ ${ }^{1}$ School of Design Art, University of South China, Hengyang, Hunan Province, 421001, China
}

\begin{abstract}
This paper introduces the present situation of the development of prefabricated buildings under the background of the development of prefabricated buildings advocated by the state. Through field visit, questionnaire survey and interview in Longfeng village, Hunan province, the present situation of the structure system of rural dwellings was investigated and researched, and its main problems were investigated and analyzed from various perspectives of energy conservation, environmental protection, thermal insulation, seismic resistance and the like. According to the survey data, this paper analyzes the difficulty of assembling rural self-built houses. Finally, the paper puts forward the corresponding development countermeasures for the construction of new rural dwellings on the road of sustainable green building, and provides strategies for the construction of new rural areas.
\end{abstract}

\section{Introduction}

Prefabricated buildings are a type of architecture assembled by prefabricated parts on the site. China began to study the design and construction technology of prefabricated concrete buildings in the 1950s and 1960s, and reached its peak in the 1980s [1]. The research data on seismic performance of rural buildings in 68 administrative villages in 19 provinces, municipalities and autonomous regions shows that masonry structure building is the most widely used structural form in rural buildings in China [2]. Village and town residence is built from house basically, and still remains in primitive and extensive type construction stage [3]. In terms of policies, the state has made specific requirements for the development of prefabricated buildings, and 57 national housing industrialization bases have been established in China [4]. However, there are still few industrialization bases for research, design and manufacturing of rural prefabricated buildings. The assembly of rural self-built houses is related to the sustainable development of rural ecological environment, so that systematic analysis on the problems of the development of prefabricated buildings in rural areas of China is required, and development strategies and suggestions should be put forward [5].

\section{Survey and analysis of folk dwellings in Longfeng village}

\section{1. building site selection characteristics of Longfeng village}

Yonghe township is located in the southeast of Hunan Hengshan county, neighbouring Xiangjiang River to the east, leaning on Nanyue to the west, and neighbouring the Hengyang city to the south. Longfeng village is located in the northwest of Yonghe township, 7-8 kilometers away from the county town, with a total area of 2.4 square kilometers. The village is surrounded by mountains and is generally high in the south and low in the north. Most local villagers choose their homestead in fields or beside mountains (as shown in figure.1). Site conditions are not taken into consideration during the site selection of the building, and the overall layout is relatively chaotic and lack of unified planning. The village road is more curved and narrower, which is not conducive to the earthquake escape and rescue.

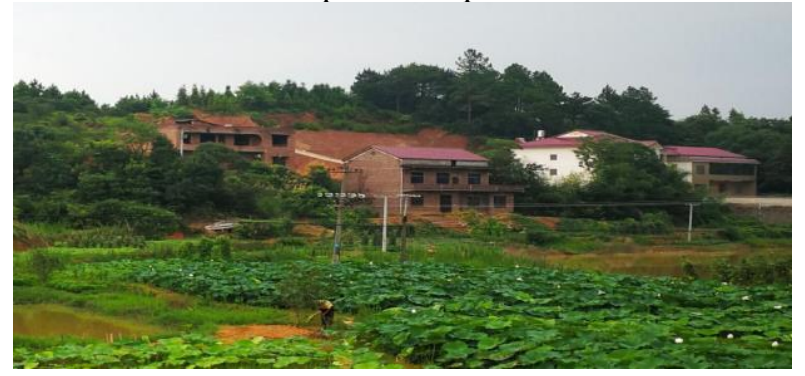

Figure 1. Longfeng village residence distribution.

\subsection{Investigation and analysis on the types of folk dwellings in Longfeng village}

\subsubsection{Timber structure dwelling.}


Longfeng village also has a small number of timber structure building system, most of which are of double slope roof. As for such buildings, solid wood, glue wood and other materials are adopted to make beams, columns and purlins; the wood-based structural plate is used as the covering plate of the floor and roof. Through investigation, it is found that the slope of wood-structure roof in this area is more than 300 , and no knot is set between the wood-structure roof and the roof base, which fails to meet the requirements of seismic fortification. In addition, the houses are in poor condition and have poor insulation; there is a cracking phenomenon on a few wood wall, its pressure-resistant capacity is quite limited, and such houses have great hidden dangers in aspects of fireproof and waterproof performances.

\subsubsection{Soil structure.}

The raw soil structure houses in Longfeng village are basically intact, and generally adopt earthen walls to support wooden house frame. The wall is made of adobe wall, adobe block wall or ramming wall. The roof and beams are of wood structure. It is mainly characterized by heavy housetop, low material strength tall room and big room width. The roof truss and wood purlin of the house are directly put on the gable without pad wood, and since the lower wall strength is not high, part of the wall under the roof truss and purlin has cracks; the longitudinal wall near the gable also has oblique cracks due to the complex force and low strength of the wall itself.

\subsubsection{Stone structure and black brick structure.}

Most of the stone structures in Longfeng village are of a certain age. As for stone houses, stone walls are adopted for bearing, most of the stone is roughly processed, and the plane layout is relatively simple and optional. The integrity and stability of the stone structures are poor. Most of them are built with regular stone or stone. Due to the thermal insulation performance of stone itself, the stone can absorb most of the heat from the solar radiation in summer, therefore, in the hot summer of Hengyang area, the thermal insulation performance of stone structure folk dwellings is quite good. Longfeng village has preserved a large number of buildings with blue brick structures. This kind of structure is adaptive to local climate conditions, good in livability and high in structural strength.

\subsubsection{Brick masonry structure dwellings.}

Brick masonry structure is a kind of house form widely used in Longfeng village at present. As for old buildings in this area, their structural foundations are built into strips with bricks and stones, and their floors and roofs are made of prefabricated boards or are cast in place, and are not equipped with ring beams and constructional columns, so that the thermal performance and comfort are relatively poor. In the newly built residential buildings, block columns are generally used to bear the load. Some horizontal walls are used as partition walls and bearing walls with spacing of $3-4 \mathrm{~m}$. Cornice walls and vertical walls parallel to the cornice walls are utilized to support the floor, so the strength and stiffness of the house basically meet the requirements. According to the limit of seismic resistance technical regulations on the floor number and height of masonry structure of rural residential buildings, the total height of houses should not be greater than $7.2 \mathrm{~m}$ and the number of floors should not be greater than 2 floors in areas with seismic intensity of 6 degrees. After sampling measurement, for Longfeng village with the seismic fortification intensity of 6 degrees, Hengshan county, Hunan province, the local limits of houses basically meet the requirements, as shown in table 1.

Table 1. Local size limit of one-masonry structure house in longfeng village (m).

\begin{tabular}{|c|c|c|c|c|}
\hline Construction site & 6 degrees & 7 degrees & 8 degrees & 9 degrees \\
\hline Minimum width of wall between Windows & 0.8 & 0.8 & 1.0 & 1.3 \\
\hline $\begin{array}{l}\text { The minimum distance between the end of the } \\
\text { load bearing outer wall and the hole }\end{array}$ & 0.8 & 1.0 & 1.2 & 1.5 \\
\hline $\begin{array}{l}\text { The minimum distance between the end of the } \\
\text { non-load bearing outer wall and the hole }\end{array}$ & 0.8 & 0.9 & 1.0 & 1.0 \\
\hline $\begin{array}{l}\text { The minimum distance between the positive } \\
\text { Angle of the inner wall and the hole of the door or } \\
\text { window }\end{array}$ & 0.8 & 0.8 & 1.2 & 1.8 \\
\hline $\begin{array}{l}\text { The minimum distance between the door and } \\
\text { window openings on the inner transverse wall and } \\
\text { the outer longitudinal wall }\end{array}$ & 0.8 & 1.0 & 1.2 & 1.5 \\
\hline
\end{tabular}

residents' self-built houses are often deeply influenced by local customs, and are incompatible with people's new way of life, so that a lot of space is wasted. There is no formal design drawing for the residential structure design. The craftsmen have great arbitrariness in construction and are lack of basic construction

\subsection{Summary of the current situation and problems of folk dwellings in longfeng village}

According to the above situation about types of folk dwellings, the existing problems of residential buildings in Longfeng village can be summarized as follows: knowledge and backward technology, resulting in high 
energy consumption and poor environmental protection for rural residential buildings.

\section{Analysis on advantages and difficulties of prefabricated buildings in the construction of new countryside}

\subsection{Rural residents know little about}

Table 2. Understanding of prefabricated buildings among residents of longfeng village.

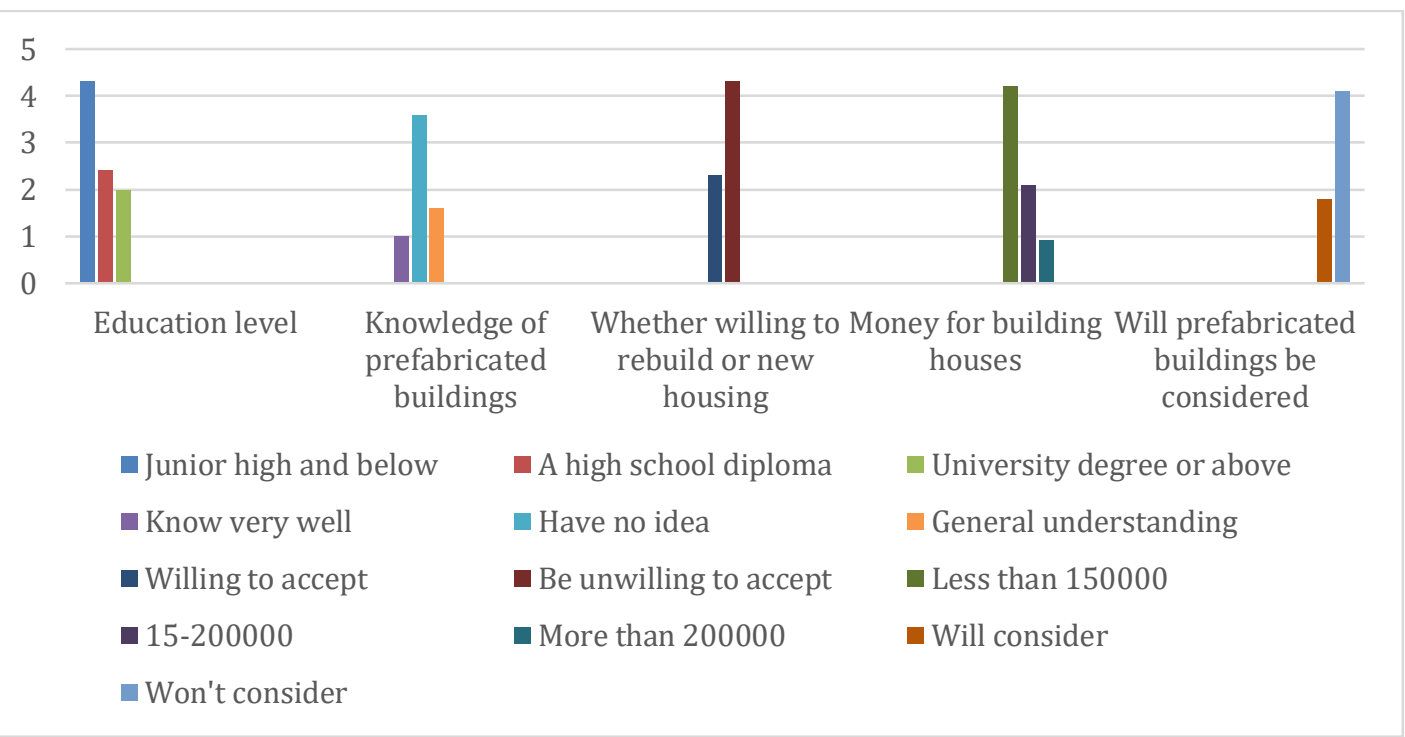

From the data in the above table, it can be concluded that the villagers in Longfeng village generally have a low education level, are in a state of ignorance and rejection of prefabricated buildings, and have insufficient funds for building houses.

\subsection{Rural prefabricated buildings have not formed a system industrial chain, the construction cost is high}

At present, there are no systemic specifications and standards for rural prefabricated buildings, and there is no product quality standard. In addition, in terms of policy, there is no corresponding incentive mechanism to promote the development of rural prefabricated buildings in local rural areas. Many prefabricated construction enterprises also lack subjective initiative and cooperation there among. This is also a direct cause of the problem that the construction cost of the current prefabricated building is much higher than that of the traditional building structure, and the promotion and development of the prefabricated building in rural areas are restricted to a certain extent.

\section{Analysis on the application of prefabricated buildings in new rural construction}

\subsection{We will increase publicity for prefabricated buildings and promote the development of pilot}

\section{prefabricated buildings, and there are} misunderstandings in their concepts.

According to the residents' understanding of prefabricated buildings in Longfeng village of Yonghe township, a survey was conducted in the form of questionnaires. A total of 300 questionnaires were distributed and 208 questionnaires were recovered. The results of statistical data are shown in the table 2 below:

\section{cities, provinces and counties}

Prefabricated buildings have unique advantages in environmental protection, thermal insulation, sound insulation and quality. It is possible to improve villagers' cognition of prefabricated buildings by combining the propaganda of preferential policies with the propaganda of knowledge. At the same time, cities and counties with better economic conditions, convenient transportation, strong willingness of farmers and certain scale of prefabricated construction will be selected to carry out pilot projects of prefabricated construction in rural areas. Through successful cases in pilot areas, more villagers can accept and approve prefabricated buildings.

\subsection{We will improve the upstream and downstream industrial chains and form an industrial scale}

Many other industries such as research and development, design, production, transportation, installation, operation and maintenance involved in the rural prefabricated construction are integrated into a complete industrial chain, so that the construction cost is lowered. At the same time, in the process of development, the advantages of enterprises in the industrial chain are continuously integrated to improve the production and transportation efficiency of prefabricated components, shorten the construction period, and promote the development of rural prefabricated buildings. 


\subsection{We will increase talent training in universities and promote the integration of industry, education and research}

At present, there is still a certain gap between rural living conditions and urban living conditions in China, which also leads to the lack of rural architectural talents. In order to better develop rural prefabricated buildings, the state or local government can properly make preferential policies to relevant talents serving rural construction, and carry out targeted talent training in related majors of architecture in universities so as to culture more talents serving rural areas and ensure that talents can be introduced and retained.

\section{Conclusion}

The construction of rural dwellings is the practice of the party central committee's scientific outlook on development, and the main content of the national new rural construction and the implementation of poverty alleviation policy. Through the field investigation of the folk houses in Longfeng village, the existing structural system and building materials of the folk houses in rural areas are discussed and summarized, and the root cause of the problem of self-built houses in rural areas is found from the perspectives of environmental protection, energy conservation, thermal insulation and earthquake resistance. This paper analyzes the difficulties of rural prefabricated buildings, and puts forward some countermeasures for the development of new rural prefabricated buildings from the measures taken by the government, the cooperation of enterprises, the cultivation of talents in universities. The emphasis is to promote the construction of green prefabricated dwellings, improve the quality of rural dwellings, improve the comfort and safety of rural dwellings, and realize the sustainable development of rural resources.

\section{Acknowledgments}

The author gratefully acknowledges the Research Foundation of Social Science Foundation of Hunan Province of China (Grant No. 18YBA370), Students' Platform for Innovation and Entrepreneurship Training Program of University of South China (Grant No. X2019117).

\section{References}

1. Jiang, Q.J. (2010) Summary of the development of prefabricated concrete architecture at home and abroad. Building technology., 41: 1074-1077.

2. Wang, Y.H., Han, G., Bu, Y.H., Li, S.R., Li, L. (2010)Analysis of seismic performance of existing masonry structure residential buildings in villages and towns. Building structure., 40: 101-104+121.

3. Shen, C. (2017) Research on the development countermeasures of prefabricated buildings in rural buildings. Science and technology economics guide.,
01: 65-66.

4. Nong, H. (2014) Development strategy research of real estate industry based on SWOT analysis. Tianjin university, Tianjin.

5. Xiao, S., Hao, S.Y., Ren, X. (2018) Research on development countermeasures of rural prefabricated buildings in China. Engineering management journal., 32: 7-11. 